\title{
How do Family Firms Grow? The Strategic Goals of Innovation and Internationalization
}

\author{
Bice Della Piana ${ }^{1}$, Alessandra Vecchi ${ }^{2}$, Vittoria Marino ${ }^{1} \&$ Mario D'Arco $^{1}$ \\ ${ }^{1}$ Department of Management \& Innovation Systems, University of Salerno, Italy \\ ${ }^{2}$ Department of Management, University of Bologna, Italy \\ Correspondence: Vittoria Marino, Department of Management \& Innovation Systems, University of Salerno, Italy. \\ E-mail: mdarco@unisa.it
}

Received: August 8, 2018

Accepted: December 20, 2018

Online Published: January 25, 2019

doi:10.5539/ijbm.v14n2p1

URL: https://doi.org/10.5539/ijbm.v14n2p1

\begin{abstract}
The aim of the paper is to identify the main strategic goals that are deemed as strategic by the owner/managers for the future growth of a family firm, and to assess how innovation ad internationalisation are included in such goals. By relying on 15 in-depth interviews with family firms' key informants (i.e. family firms' owners, managers and professionals), the study makes an original contribution that is significant and relevant both from a theoretical and a methodological perspective. In relation to the former, it provides a comprehensive review of the main family business goal setting models in order to identify the relevant categories used to classify the goals. Additionally, differently from extant research the study outlines the pivotal importance of innovation and internationalization as strategic goals for family firms' growth. In relation to the latter, by relying on a narrative approach, the study provides a finer-grained understanding of how internationalization and innovation are conceived with respect to traditional characteristics of the family firms.
\end{abstract}

Keywords: family firm, strategic goals, internationalization, innovation, narrative approach

\section{Introduction}

A large part of research on family firms is based on the investigation of family firms' goals and the diversity of topics related to family firms' goals. Specifically, substantial attention is given to the family firms goals setting process and the mechanisms through which family firms goals are formed and how outcomes are achieved (Williams et al., 2018).

Contrary to the classical theory which assumes profit or value maximization as the main goal pursued by the family firms, behavioural theorists have suggested that firms have a variety of non-economic as well as economic goals (Argote \& Greve, 2007; Cyert \& March, 1963). Chrisman et al. (2012), highlight that some kinds of goals originate from the emotional value of family properties (Astrachan and Jaskiewicz, 2008; Zellweger and Astrachan, 2008), from the importance of family social capital (Arregle et al., 2007; Pearson et al., 2008) and by the emphasis on the creation and preservation of the family socio-emotional wealth (Gomez-Mejia et al., 2007). Similarly, stakeholder theory (Freeman, 2010; Mitchell et al., 1997), starting from the assumption that family firms have unique and powerful stakeholders (i.e. the family), supports the importance of family-centered non-economic goals and provides a complementary view in the identification of non-economic goals such as 'family harmony' and 'social status'. Additionally, Berrone et al. (2012) pointed out that altruism, fairness, justice and generosity represent the main goals of family firms.

This heterogeneity among family firms' goals is due to the distinctive values and socio-cultural characteristics of the subject involved in the decision-making process. Thus, according to Williams et al. (2018), the presence of an owning-family and its control over the business represents a significant family firms' goal antecedent.

In order to nurture the debate about the diversity of topics related to family firms' goals, the aim of this study is to identify the main goals that are deemed as strategic by the owner/managers for the future growth of a family firm, and to assess whether innovation ad internationalisation are included in such goals. The contribution of the study is threefold. First, it provides a comprehensive review of the main family business goal setting models in order to identify the relevant categories used to classify the goals. Second, differently from extant research the study outlines the pivotal importance of innovation and internationalization as strategic goals for the family firms' 
growth. Thirdly, by relying on a narrative approach, two other specific contributions are made. The study provides a finer-grained understanding of how internationalization and innovation are conceived with respect to traditional characteristics of the family firms. Specifically, from the findings it emerges that internationalization is the most important strategic goal for family firms' future growth. However, its adoption tends to be a gradual process due both to the limited resources that traditionally characterize family firms and to the family business's prudential approach that is aimed at preserving the family's wealth. The other specific contribution relates to the need to distinguish between current and future goals.

The rest of the paper is organised as it follows. First, we present a theoretical overview of the main family firms' goal setting models existing in the literature. Second, we outline the research design adopted by this study and we illustrate the uses and potentials of narrative analysis for family business research. Third, we apply narrative analysis to the data collection which consists in 15 in-depth interviews with owner/managers of selected family firms. Finally, we present the main findings and discuss their limitations as well as their implications for future research.

\section{Theoretical Background}

\subsection{Family Businesses Goal Setting Models}

Family firms are defined, theoretically, as businesses "governed and/or managed with the intention to shape and pursue the vision of the business held by a dominant coalition controlled by members of the same family or a small number of families in a manner that is potentially sustainable across generations of the family or families" (Chua et al., 1999, p. 25). This definition has some interesting feature. First, it highlights the family presence as a significant antecedent of the business. Second, it considers the family vision and its managerial logic as fundamental drivers for the success and longevity of the firm. Thus, the presence of an owning-family and its control over the business represents a significant family firms' goal antecedent (Williams et al., 2018). Due to this fact, the goal setting process is one of the main topics in family firms research. Specifically, Basco (2017) focusses on the introduction of a theoretical model that is apt to address the following basic question: "what does family business goal mean?" and gather together the collection of goals pursued by the family taking into account the family ownership, the firm and its entrepreneurial context. This means that in family firms the owner, or a dominant group, combines both the financial aspects of the firm and the non-financial aspects, namely the socio-emotional wealth of the family (Berrone et al., 2012), or the family's affective needs (Gòmez-Mejia et al., 2007). Therefore, it can be argued that the concept of family business goals is intrinsically multidimensional. Specifically, according to Basco (2017), family goals are based on the nature of economic and non-economic goals combined with specific orientations, that is family and business orientations. At an abstract level, as depicted in Figure 1, there are four different interrelated constructs that define the structure of family firms' goals.

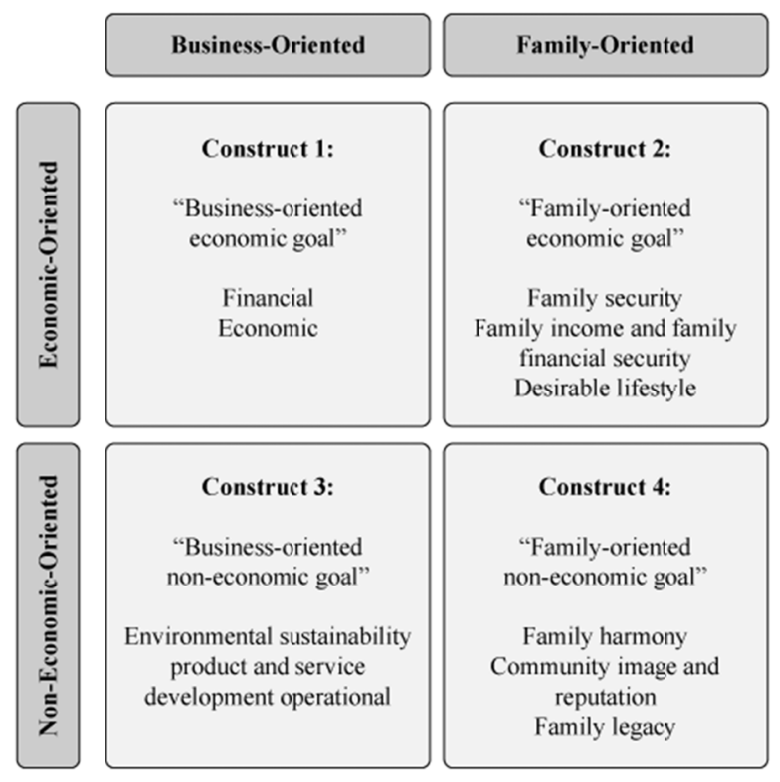

Figure 1. Dimensionality of family business goals (Adapted from Basco, 2017, p. 5). 
According to Kotlar and De Massis (2013, pp. 1264-1265) "defining the goals adopted by an organization requires specifying who is able to influence firm decision, the element that may affect their individual goals and, more importantly, the processes through which the individual preferences are translated into organizational policy and action".

Considering the differences among the types of family firms and organizational members Kotlar and De Massis introduced a taxonomy of four goal categories. As shown in Figure 2, the taxonomy defines the type of goals taking into account two main dimensions: the goal content (i.e., economic, non-economic), and the goal recipient (i.e., family, non-family).

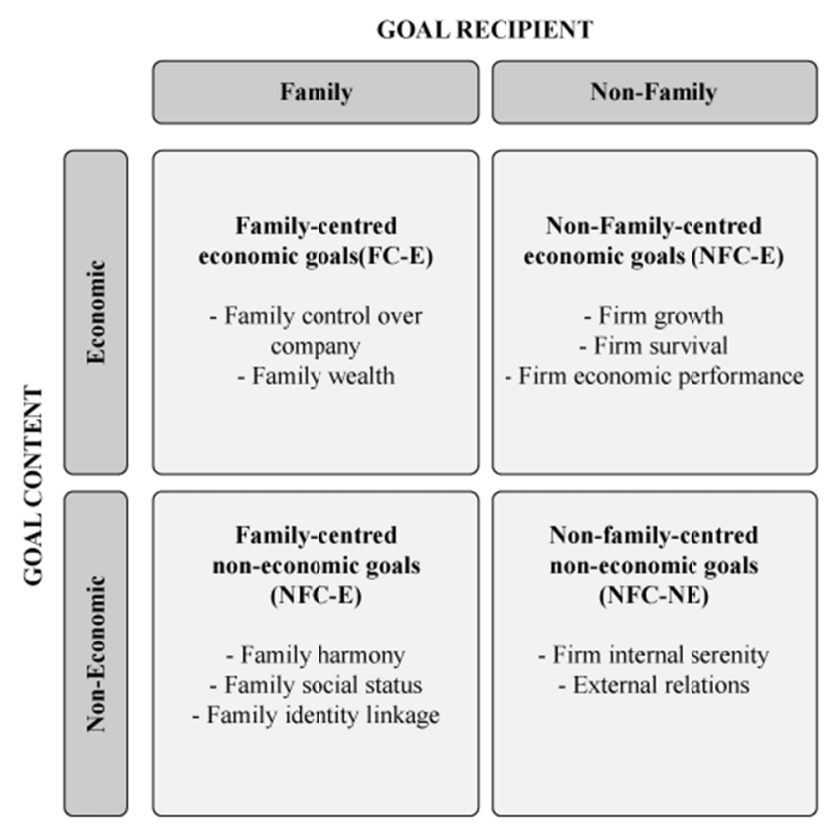

Figure 2. Members' goals in family firms (adapted from Kotlar \& De Massis, 2013, p. 1272).

The first goals category is Family-Centred Non-Economic goals (FC-NE). These types of goals may change over time and reflect the attitudes, values, perceptions and intentions of the family firm's coalition members. The main Family-Centred Non-Economic goals identified by Kotlar and De Massis are family harmony, the family's social status and its reputation, as well as the family identity linkage.

The second category of goals is Family-Centred Economic goals (FC-E). In this case, the interest of the family consists in the maintenance of family control over the firm and the preservation of wealth created by the family throughout its history.

The third category of goals is Non-Family-Centred Non-Economic goals (NFC-NE). These types of goals, such as the improvement and conservation of good relationships with internal and external stakeholder, as underlined by Kotlar and De Massis (2013, p. 1273) "intended to satisfy other stakeholders than the family and were not related to economic aspects".

The fourth category of goals is Non-Family-Centred Economic goals (NFC-EC). These types of goals, which include different indicators of economic performance such as growth, survival and the profit of the enterprise, are not explicitly oriented to the family and are strictly related to the economic aspects of business.

Focusing on the taxonomy just described, we can see that this model is useful for showing the goal diversity in family firms, but it does not explain how the goals that are associated with pursuing future growth are implemented. This gap in the literature about the specific goals of growth represents a valuable research opportunity. As highlighted by Chrisman et al (2012, p. 268) “an understanding of a family firm's goals should be a precursor to understanding its behaviours and performance". To this purpose, there is a need to identify such goals first and to critically assess how they are perceived with respect to all the others in order to reach a fuller understanding of the 
vision that family businesses have about their own growth.

\subsection{Family Firms' Goals of Growth: Internationalization and Innovation}

Recent literature reviews (Arregle et al., 2017; Della Piana and Vecchi, 2017; Pukall and Calabrò, 2014) show that internationalization is an important strategic element in the pursuit of growth for family firms. However, at the same time, the literature on family business highlights that family ownership might assume contradicting results in terms of internationalization. In fact, the family ownership can either boost its internationalization or hinder it (Arregle et al., 2007; Calabrò et al., 2013; Holt, 2012).

Another driving forces underlying economic growth, competitive advantage and success of family firms is innovation. While some studies provide empirical evidence with regard to negative associations between family firms and innovation (Block, 2012; Chen and Hsu, 2009; Chrisman and Patel, 2012; Munari, Oriani, and Sobrero, 2010), others find that innovation has both a positive impact on the long-term business performance of family firms (Alberti and Pizzurno, 2013; Kellermanns et al., 2012; Partanen et al., 2014 ; Uhlander et al., 2013) and on their survival against competitors (Carnes and Ireland, 2013; De Massis et al., 2016).

On the basis of this discussion, the objectives of this explorative study are to address the following research questions:

RQ1: What are the main goals considered strategic by the owner-managers for the future growth of a family firm? RQ2: Are innovation and internationalisation perceived by the owner-managers as strategic goals for firm growth?

RQ3: How do non-economic goals affect the family businesses' future growth prospects?

\section{Methodology}

\subsection{Research Design}

Given the unobservable nature of family business goals (Basco, 2017) and the need to identify the firms' growth goals as perceived by the family members, narrative analysis seemed the most appropriate research approach for the purpose of this exploratory work.

Narrative analysis is a method of qualitative research that "uses stories as data" (Merriam, 2009, p. 32) to capture "life experiences of a single life or lives of a small number of individuals" (Creswell, 2007, p. 55). Therefore, this method is useful to provide "insights into people's thoughts, emotions and interpretations" (Thomas, 2012, p. 209) and to explore the meaning of everyday practices in communication studies (Fisher, 1984; 1987), anthropological psychology and therapy (Polkinghorne, 1988), cognitive psychology (Bruner, 1986; 1990), economics (McCloskey, 1985), anthropology (Geertz, 1973; 1988), sociology (Abell, 1987; 2004; Franzosi, 1998; Marsiglio \& Cohan, 2000; Polkinghorne, 1988), marketing (Thompson, 1997), and organization and management studies (Boje, 1991; Brown, 2006; Czarniawska, 1997; 1998; O’Connor, 1995; Oliver \& Roos, 2005; Rappaport, 1993; Starkey \& Crane, 2003).

Individuals in a family business organise their entrepreneurship experience in a narrative way. The family business identity, the organization's culture, the knowledge sharing among the employers, the strategies, the goal setting are all (co-)constructed through language. Thus narratives, as a form of phenomenological inquiry (Cope, 2005; Hamilton et al, 2017), can be very useful for researchers to better understand the process of being and becoming a family business. During the interview, the experiences are reconstructed and thereby jointly understood by the narrator and the researcher (Rosenthal and Fischer-Rosenthal, 2004).

The narrative material on which the analysis relies on are the transcripts of the 15 interviews conducted with owner-managers of family firms from different industries. Taking into account the polar sampling technique (Eisenhardt \& Graebner, 2007), which is widely used in family businesses case studies (De Massis \& Kotlar, 2014), the selected interviews are considered as extreme cases along a selected dimension. As suggested by De Massis and Kotlar (2014, p. 18): "The selected cases should offer enough distinct windows through which to observe an investigated phenomenon in a unique and extraordinary way."

The dimension we adopted for our analysis is the condition of being or not being a member of the family. Additionally, a further distinction has been made within the family members, between founders and successors of the second and third generation.

\subsection{Data Collection}

Data collection about the family businesses' strategic goals was conducted in the context of broader research whose main purpose was to analyse competitive strategies, innovation dynamics and international development of 
Small and Medium Enterprises (Izzo, 2017). Data were collected by relying on an in-depth semi-structured interview which was administered to the interviewees. For this research 15 family firms were selected on the basis of the following criteria: (i) the firm is located in Italy, and more specifically in the Campania region; (ii) the firm is family-owned; (iii) the interviewee is a member of the family (founder or successor to the founder), or an external member.

The interviewees were selected according to their relevance to the overall objective of the research project. These were namely the founders, the CEOs, the managing directors, and the general managers. The questionnaire was designed to highlight the 'common starting points' (Van Riel, 2000); that is, the keywords that were used to describe the firm's growth goals. In line with the criteria used by Kotlar and De Massis (2013), family firms are defined by three requirements: 1) the majority of the firm is owned by the family, 2) two or more family members were actively involved in the company, 3) the interviewees perceive the company as the family firm. Finally, a distinction amongst the interviewees allowed the classification of the 15 family-owned selected cases into 3 groups (as illustrated in the Table 1): 5 in which the interviewees are founders or successors of second generation (companies from A1 to A5); 5 in which successors are from the third generation onwards (companies B1 to B5); 5 in which the interviewees are professionals who work in the family firm but do not belong to the family (companies $\mathrm{C} 1$ to $\mathrm{C} 5$ ).

Table 1. Family firms and interviewees' demographic profiles

\begin{tabular}{lrcc}
\hline Firm & Sector & Age of the firm & Interviewee \\
\hline A1 & Mechanical & 2 & Founder \\
A2 & Metal & 3 & Owner 2 ${ }^{\text {nd }}$ generation \\
A3 & Graphics & 3 & Owner 2 generation $^{\text {nd }}$ \\
A4 & Food & 2 & Founder \\
A5 & Food & 2 & Founder \\
B1 & Clothing & 3 & Owner $3^{\text {rd }}$ generation \\
B2 & Mechanical & 3 & Owner $3^{\text {rd }}$ generation \\
B3 & Food & 3 & Owner $3^{\text {rd }}$ generation \\
B4 & Electrical appliances & 2 & Founder's son (no longer owner) \\
B5 & Metal & 2 & Owner $3^{\text {rd }}$ generation \\
C1 & Metal & 2 & Professional \\
C2 & Mechanical & 3 & Professional \\
C3 & Food & 2 & Professional \\
C4 & Metal & 2 & Professional \\
C5 & Furniture & 2 & Professional \\
\hline
\end{tabular}

*Firm classification based on interviewee characteristics: $\mathrm{A}=$ founder or second generation, $\mathrm{B}=$ third generation, $\mathrm{C}=$ =professional

**1=Young (less than 10 years); $2=$ Mature (between 11 and 50 years); $3=$ Long-lasting (more than 50 years).

The analysis of the qualitative data allowed us to map out the growth goals of the firms, to detect their priorities and to formulate hypotheses about the influence of non-economic goals and how these might affect the firms' growth by considering the family involvement in the business (for example, in the executive board, or in top management positions), the extent to which the firm is open to the involvement of professionals in the role of owners, directors, managers or consultants and, finally, the relationships established by the company and its distinctive features. With specific reference to the interviews, from the outset of the data collection process a key informant from the firm (the founder, the successor or a manager) was contacted by sending him/her a written summary of the research project, and a follow-up call was made. According to De Massis and Kotlar (2014. p. 21), "the views of family members may systematically vary from those of non-family members because the family status or organizational roles of both influence their interpretations." Each interview lasted about an hour and a half, for a total of 22.5 hours of interviews. The interviews followed a semi-structured protocol that included a set of open and closed questions (as outlined in Table 2). Given the purpose of the study, the interview method seemed appropriate since the aim was to gain an in-depth understanding of the issues that the interviewees considered to be important for the performance and the future development of the firm. Secondary data were collected from the AIDA and AMADEUS databases, from business reports and official websites. In particular, all the documents and information materials available on the family firms was analysed in order to collect thorough information about the strategic goals of the selected firms in terms of typology, variety and priorities. Following the study of De Massis and others $(2012$, p. 21$)$, this secondary information was integrated by relying on a process of triangulation with 
those obtained from our interviews "in order to avoid post hoc rationalization and to ensure construct validity." Triangulation provided the possibility to adopt different perspectives to observe the same phenomenon (Denzin, 1994; Jick, 1979; Pettigrew, 1990; Stake, 2013; Yin, 1994). As suggested by De Massis and Kotlar (2014), the triangulation of evidence derived from multiple data sources is particularly important for family business research, where it is difficult to separate the aspects entirely related to the family sphere from those specifically related to the business's decisions. In order to simplify the explanation and the representation of the empirical evidence, data from multiple sources (results from the interviews, key documents, selected quantitative data stemming from the interviews), were organised in a database to make the analysis more rigorous and therefore the findings more robust.

Table 2. Semi-structured questionnaire

\begin{tabular}{ll}
\hline Relevant information & Data source \\
\hline & Ownership \\
Involvement of the family & Executive board (including the CEO) \\
& Top Management \\
Degree of opening & Professionals \\
Company Growth & Turnover (domestic and international) \\
Actual Growth & Innovation (product, process, organisation) \\
Future Growth & Internationalisation (UE, Non-UE) \\
& Open question \\
Relationships & Innovation \\
Distinctiveness & Internationalisation \\
\hline
\end{tabular}

\subsection{Data Analysis}

The information obtained were further refined for the final analysis through three processes: data reduction, data display and data categorisation; finally, techniques for data contextualisation were used (De Massis and Kotlar, 2014). The process of data reduction implied the selection and the simplification of the relevant data that was deemed as more relevant to address the research questions. The process of data display made it possible to simplify the identification of those themes that were deemed as useful to the analysis (as illustrated in Tables 3, 4, 5 and 6 respectively, see Appendix). Data categorisation involved first the distinction and then the grouping of different categories of information in order to facilitate the comparison amongst the interviews (as illustrated in Table 7).

Table 3. Family involvement in the ownership, governance and management

\begin{tabular}{|c|c|c|c|}
\hline Firm & Ownership* & EB/CEO** & Top Management $* * *$ \\
\hline A1 & 3 & 3 & 3 \\
\hline A2 & 3 & 3 & 3 \\
\hline A3 & 3 & 3 & 3 \\
\hline A4 & 3 & 3 & 2 \\
\hline A5 & 3 & 3 & 3 \\
\hline B1 & 3 & 3 & 3 \\
\hline B2 & 3 & 1 & 3 \\
\hline B3 & 3 & 3 & 3 \\
\hline B4 & 3 & 3 & 3 \\
\hline B5 & 3 & 3 & 3 \\
\hline $\mathrm{C} 1$ & 3 & 3 & 3 \\
\hline $\mathrm{C} 2$ & 3 & 3 & 3 \\
\hline $\mathrm{C} 3$ & 3 & 3 & 3 \\
\hline $\mathrm{C} 4$ & 3 & 3 & 1 \\
\hline C5 & 3 & 3 & 3 \\
\hline
\end{tabular}

*Family involvement in ownership: $0: f=0,1: f<50 \%, 2: f>=50 \%, 3: f=100 \%$

** Board of Directors composition: $0: f=0,1: f<50 \%, 2: f>=50 \%, 3: f=100 \%$

*** Family involvement in top management: $0: f=0,1: f<50 \%, 2: f>=50 \%, 3: f=100 \%$ 
Finally, thanks to data contextualisation detected through the narrative analysis, the relevant connections between the collected data were identified (as shown in Figures 3 and 4 respectively, see Appendix). Table 3 shows the family involvement in the business activities. All the cases selected for the study reveal that the family represents the dominant group within the organization. In 11 out of the 15 cases (i.e. A1, A3, A5, B1, B2, B5, C1, C2, C3, C4, C5), ownership is shared amongst more than two partners: parents, brothers, sons, cousins or other family-controlled firms (i.e. B5, C2). Only one case (B3) did not show a total involvement of the family owners in the executive board as the company CEO is a father who has sold his shares to his children, and only in one case (i.e. B2) does the family not hold $100 \%$ of the votes on the executive board (executive board composition: father board chairman; son - vice-chairman; daughter - adviser; 10 managers). Finally, in all cases family members have key roles in the top management.

Table 4. Degree of firm openness

\begin{tabular}{lc}
\hline Firm & Opennes to external members* \\
\hline A1 & 3 \\
A2 & 0 \\
A3 & 2 \\
A4 & 0 \\
A5 & $2 ; 3$ \\
B1 & 3 \\
B2 & $2 ; 3$ \\
B3 & 3 \\
B4 & 0 \\
B5 & 0 \\
C1 & 3 \\
C2 & 3 \\
C3 & 3 \\
C4 & 0 \\
C5 & 0 \\
\hline
\end{tabular}

* Presence of non-family members: $0=$ no non-family members;

$1=$ non-family members in the ownership, $2=$ non-family members in the executive board; 3 =non-family members in the top management.

Table 4 shows the information on the degree of openness to the involvement of professionals or external members in the ownership, the executive board and the top management. In only three case studies (A3, A5, B2) was there a very high degree of openness to members outside the family in the executive board and in 7 case studies (i.e. A1, A5, B1, B3, C1, C2. C3) to key roles in the top management; in 4 companies (A5, B2, B3, C3) a significant number of external members were observed in the top management (i.e. General Manager, Head of Research \& Development, Production Manager, Country Manager). In these companies, the degree of openness to external members is limited to the position of advisor, and largely in relation to the preparation of financial statements. 
Table 5. The family businesses' distinctive features

\begin{tabular}{|c|c|}
\hline Firm & Distinctive features \\
\hline A1 & The firm's culture; Innovation, product's safety, risk assessment of the country; Managing diversity (gender, cultural), CSR \\
\hline A2 & $\begin{array}{l}\text { Selling abroad; Being an Italian firm; Being a family business allows to establish personal relationships; Risk assessment of the } \\
\text { export portfolio }\end{array}$ \\
\hline A3 & $\begin{array}{l}\text { Endless love for the business. I was teaching in school but still went to work with my father in the company; I have never worked } \\
\text { for the money; A gradual growth. Our growth relates to our know-how and not to our size; We have been pioneers of innovation } \\
\text { to compensate for our lack of resources }\end{array}$ \\
\hline A4 & Collaboration to acquire new market knowledge and innovation; New processes, new products; Relentless search of new markets \\
\hline A5 & Craftsmanship and innovation at the same time; Being organised and cross-functional collaboration \\
\hline B1 & $\begin{array}{l}\text { Quality of our product and our service to the customer; Well-defined identity; To keep the family cohesive; Long experience in } \\
\text { the sector }\end{array}$ \\
\hline B2 & $\begin{array}{l}\text { Continuous innovation; Establish partnerships to sell products and to conduct research. Comparing notes is a way to improve our } \\
\text { product; Process capability ( } 1000 \text { machines installed all over the world); } 40 \text { Patents }\end{array}$ \\
\hline B3 & $\begin{array}{l}\text { Excellent product, exactly the same in every country; We are not willing to compromise on our values Personal relationships } \\
\text { facilitate long-term relationships outside the firm }\end{array}$ \\
\hline B4 & $\begin{array}{l}\text { We make everything ourselves; We spend time looking for something innovative every day; Enthusiasm and the founders' } \\
\text { skills }\end{array}$ \\
\hline B5 & $\begin{array}{l}\text { The company has totally reacted to the changing market trends by radically changing its production (from the production of } \\
\text { curtains to metal manufacturing); Ability to make the most of public funding; Gradual growth (1-2 investments every } 10 \text { years) } \\
\text { to keep the finances in order; Despite } 3 \text { families being involved, managing the business can be attributed to only one person }\end{array}$ \\
\hline $\mathrm{C} 1$ & $\begin{array}{l}\text { Strong and fast decision-making process; The owners are the dominant players; A company cannot rely on friendship but it has } \\
\text { to rely on professionalism }\end{array}$ \\
\hline $\mathrm{C} 2$ & $\begin{array}{l}\text { Investing in technology and capabilities. Besides the investments we have been lucky to acquire capabilities from outside; A } \\
\text { flexible organisation that enables us to be responsive; The firm's growth has been fed by the founder's strong belief in the } \\
\text { business; In the company if you're worthy you can progress; The family is planning to stay involved in the business for a long } \\
\quad \text { time }\end{array}$ \\
\hline $\mathrm{C} 3$ & $\begin{array}{l}\text { Our company has been the first one to launch direct sales; The owners were totally reluctant to establish any collaboration to } \\
\text { open another facility outside }\end{array}$ \\
\hline $\mathrm{C} 4$ & The management prefers to get them young, get them trained and then to get them to work for them \\
\hline $\mathrm{C} 5$ & $\begin{array}{l}\text { A deliberate strategic choice that has allowed us to work in a context characterised by demand in excess; Continuous } \\
\text { improvement; Experience }\end{array}$ \\
\hline
\end{tabular}


Table 6. Relationship with the stakeholders

\begin{tabular}{|c|c|c|}
\hline Firm & Relationships or innovation & Relationships for internationlisation \\
\hline A1 & Suppliers & Local dealers that are trained in-house \\
\hline A2 & $\begin{array}{l}\text { No formal agreement but strong collaboration with the customers } \\
\text { who are supported when they buy machinery as well as raw } \\
\text { materials }\end{array}$ & $\begin{array}{l}\text { Direct export without export agencies (staff recruitment } \\
\text { for SMEs that wish to grow further) }\end{array}$ \\
\hline A3 & $\begin{array}{l}\text { Suppliers; acquisition of } 50 \% \text { of another Italian company } \\
\text { characterised by strategic know-how in digital printing; strong } \\
\text { collaboration with professional advisors for the FROGA } \\
\text { certification }\end{array}$ & None \\
\hline A4 & $\begin{array}{l}\text { Acquisition of a company. Strong collaboration with established } \\
\text { large firms as they provide crucial input for strategic know-how. } \\
\text { Strong collaboration with universities (packaging, unique in } \\
\text { Europe) }\end{array}$ & $\begin{array}{l}\text { Direct exports } \\
\text { Initial collaboration to acquire some market knowledge } \\
\text { then direct exports } \\
\text { Longstanding relationship with an MNC to acquire global } \\
\text { market knowledge }\end{array}$ \\
\hline A5 & $\begin{array}{l}\text { Collaboration with universities to establish new production } \\
\text { processes }\end{array}$ & None \\
\hline B1 & $\begin{array}{l}\text { Suppliers to implement technical changes to the fabrics and other } \\
\text { domestic collaborations that have enabled us to develop the } \\
\text { company further }\end{array}$ & $\begin{array}{l}\text { Subsidiaries in USA and Japan. Franchising agreements in } \\
\text { China for the brand 'Isaia'; Important retailer in Boston; } \\
\text { Foreign market entry through agents first then by } \\
\text { establishing subsidiaries in USA and Japan. }\end{array}$ \\
\hline B2 & $\begin{array}{l}\text { Customers to implement innovations (the machinery is designed on } \\
\text { the basis of their specifications) }\end{array}$ & $\begin{array}{l}\text { Industrial partners, agents and customers. Strong } \\
\text { relationships are required to internationalise. Establishing } \\
\text { some market presence is India has required considerable } \\
\text { time and effort ( } 25 \text { years). The commercial partners and } \\
\text { the professional advisors have paved the way into the } \\
\text { Indian market. }\end{array}$ \\
\hline B3 & No formal agreement but we collaborate with our customers & $\begin{array}{l}\text { Direct exports by relying on distributors. Strong } \\
\text { collaboration with an African company that has allowed } \\
\text { us to enter the market by relying on a 'gentleman's } \\
\text { agreement'. A relationship characterised by a high level of } \\
\text { trust. }\end{array}$ \\
\hline B4 & No formal agreement but we collaborate with our suppliers & $\begin{array}{l}\text { Direct exports. In the past we worked with Whirlpool and } \\
\text { we relied on people who were fluent in English. Today in } \\
\text { our company everybody is fluent in at least two foreign } \\
\text { languages. }\end{array}$ \\
\hline B5 & $\begin{array}{l}\text { Machinery suppliers that are located across several geographical } \\
\text { locations to come up with the best solutions }\end{array}$ & None \\
\hline $\mathrm{C} 1$ & None & Direct exports with agents and sales representatives \\
\hline $\mathrm{C} 2$ & $\begin{array}{l}\text { Universities and research centres for innovation and we collaborate } \\
\text { with both foreign and domestic suppliers }\end{array}$ & $\begin{array}{l}\text { We were used to relying on agents who were } \\
\text { knowledgeable about Latin America and Spain. For the } \\
\text { Emirates we had a Lebanese agent. Now we have sales } \\
\text { offices in Dubai and Casablanca. We are planning to open } \\
\text { sales offices in Brazil and China. In Morocco we have a } \\
\text { local maintenance company. }\end{array}$ \\
\hline $\mathrm{C} 3$ & None & None \\
\hline $\mathrm{C} 4$ & None & $\begin{array}{l}\text { Local firms, distributors but also direct contacts with the } \\
\text { customers }\end{array}$ \\
\hline $\mathrm{C} 5$ & $\begin{array}{l}\text { Suppliers (aircraft manufacturers to improve both the product and } \\
\text { the production processes), universities and research centres. }\end{array}$ & Direct contacts with customers and clients \\
\hline
\end{tabular}

Table 6 shows the distinctive features of the firms according to the perceptions of the interviewees (their direct quotes are shown in italics in the table). This information is considered particularly important for the critical assessment of non-economic goals in relation to the firm' growth. With specific reference to those goals related to the family sphere, in 8 cases out of 15 the respondents freely expressed that 'being a family firm' is a distinctive feature. For example, an interviewee (A2) stated: 'being a family firm has allowed them to establish business relations with North African countries which required the establishment of a relationship of trust before they could even negotiate any business deal'; in the case of B3, the interviewee pointed out that 'being a family firm allowed members to establish personal and, thus, more enduring relationships'. 'Tenacity' as well as 'enthusiasm of the owners' are perceived as a critical element for the firm's success (B4 and C2). Finally, the unity of the family 
purpose, either as a purely affective element and in the governance of the firms, is perceived as a distinctive element as well as a purpose to maintain over time (B1 and B5). As for the non-economic goals that are closely linked to the business, the findings demonstrate the importance of two features that make these firms different from others. These are the 'pursuit of a gradual growth', and the 'harmony within the firm'. Indeed, it is possible to notice that 'gradual growth' is an element of key importance that needs to be preserved over time in terms of economic and financial balance as well as the 'relationships amongst the family members' (see for example A3 and B5). Keeping good relationships both within the family members and stakeholder (i.e. Employers, suppliers, customers and so on) is perceived as a crucial requirement that enables the growth of the firm.

Since it has been highlighted several times by the interviewees as a distinctive feature, the relationships with the external stakeholders of the firm were considered separately in order to highlight more emphatically their importance for the future growth goal. The direct quotes of the interviewees in Table 6 explain the role that these relationships have played in the development of the firms analysed (with the exception of C3), and with specific regard to innovation and expansion in foreign markets. Generally speaking, the most cited stakeholders are suppliers, customers, other companies, universities and sales representatives. According to the interviewees, relationships with the suppliers, universities and research centres are the most relevant to the development of new products while those with sales representatives and distributors have represented, and still represent, a reference point for international expansion. It is interesting to note that in some cases the relationships with external stakeholders are not considered as necessary to innovate (A2, B3, B4, C1, C3, C4) and to internationalise (A3, A5, $\mathrm{B} 5, \mathrm{C} 3)$. Conversely innovation, for the first group of firms, and internationalisation, for the second group, are not considered as priorities in the goals for future development of such firms.

\section{Discussion of the Findings}

Family firms' goals and determinants of growth are nowadays relatively popular topics of discussion among scholars. Many authors claim that the pursuit of family-centred objectives, both economic and non-economic, represent a distinctive feature of family firms (Chrisman et al., 2005) although this varies from firms to firms (Westhead \& Howorth, 2006). Despite the literature underlines the relationship between family involvement and the adoption of family-centred goals, it is unclear what family businesses' future goals are considered strategic for the family members. From the findings it emerges that a proper distinction should be made by considering both the current and future family firm's goals in order to better understand the determinants of the vision of the future growth path according to both the family members and those external to the firms.

By endorsing the view that there is a remarkable interplay between the goals related to the family and those strictly related to the business's activities as well as the influence of non-economic goals on the economic ones, the present work has contributed to the wide debate on the pivotal role that narratives has in classifying those determinants that cannot traditionally be assessed by relying on quantitative approaches. More precisely, the interpretation of the narrative materials obtained by the respondents allowed us to identify the distinctive features that characterise family businesses' growth goals.

As illustrated in Figures 3 and 4, the goals of family businesses were classified into current and future goals. Taking in consideration the taxonomy proposed by Kotlar and De Massis (2013) it is possible to notice several striking features. First, it is immediately visible that the subcategory of 'family wealth' in the FC-E is absent from both their current and future goals. Among the FC-NE our interviewees never mention 'family harmony', the 'family social status' and 'the family identity'. By contrast, 'family values', 'resilience' and the 'strategic guidance of the family' have been listed amongst the current goals but they do not appear amongst the future goals. 


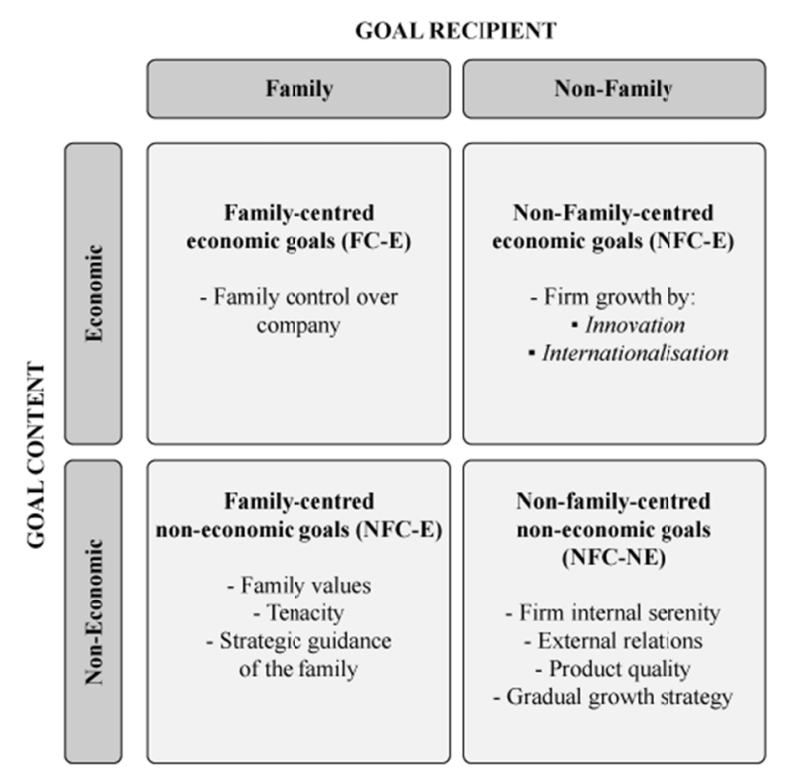

Figure 3. The current goals as they emerged from the data analysis

As for NFC-NE goals, from the findings it emerges that these as current goals are consistent with firm 'internal harmony' and 'external relations'. 'Harmony' and 'external relations' were deemed by the interviewees as instrumental both for the development of innovation (A1, A3, A4, A5, B1, B2, B5, C2) and for internationalisation (A1, A4, B1, B3, B5, C1, C2). 'Product quality' and 'the gradual growth strategy' (perceived as a means of consolidation of the position reached by the company in the past) were also mentioned by the interviewees as amongst the current goals. Such goals, along with the definition of the business strategy and the external relations, are of particular interest since they were mentioned in a few instances. Finally, with reference to the NFC-E, the findings were classified into two typologies: the innovation-based growth and the internationalisation-based growth. Such a distinction is absent from the matrix of Kotlar and De Massis (2013).

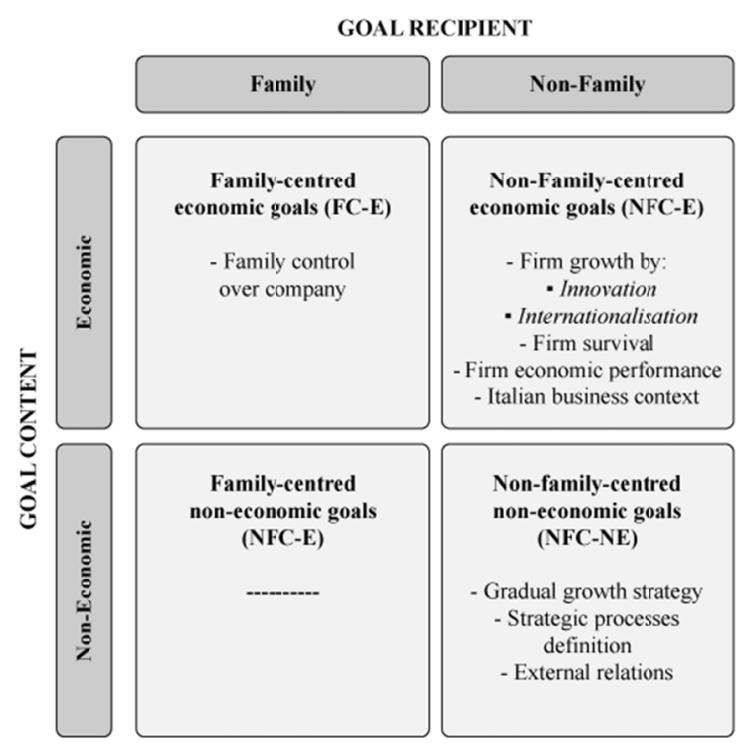

Figure 4. The future goals as they emerged from the data analysis 
Table 7. Firms' growth goals mapping

\begin{tabular}{|c|c|c|}
\hline $\begin{array}{l}\text { Firm } \\
(\mathrm{NT}) *,(\mathrm{IT}) * *\end{array}$ & Current growth & Future growth \\
\hline A1 & Product innovation, process innovation and management innovation & Internationalisation \\
\hline NT: 1, IT: 2 & $\begin{array}{l}\text { Internationalisation: Europe } 80 \% \text { (Greece, Libya, Tunisia, Egypt; Outside Europe } 20 \% \\
\text { (Emirates, Africa and others) }\end{array}$ & \\
\hline $\mathrm{A} 2$ & Product innovation, process innovation and management innovation & Internationalisation \\
\hline NT: 1 , IT: 3 & $\begin{array}{l}\text { Internationalisation: Europe (Spain, France); Outside Europe (Algeria, Morocco, Russia, } \\
\text { Saudi Arabia) }\end{array}$ & Consolidation \\
\hline $\begin{array}{l}\text { A3 } \\
\text { NT: } 2\end{array}$ & Process innovation and management innovation & Innovation \\
\hline A4 & Product innovation, process innovation and management innovation Internationalisation: & Turnover \\
\hline NT: 3 , IT: 3 & $\begin{array}{l}\text { Europe (all countries); Outside Europe (Arab countries, South Africa, Australia, New } \\
\text { Zealand) }\end{array}$ & $\begin{array}{l}\text { Internationalisation } \\
\text { Consolidation }\end{array}$ \\
\hline A5 & Product innovation, process innovation and management innovation & Internationalisation \\
\hline NT: 3, IT: 3 & Internationalisation: Europe (Germany); Outside Europe (USA, Emirates) & Turnover \\
\hline B1 & Product innovation and management innovation & Internationalisation \\
\hline NT: 3 , IT: 3 & $\begin{array}{l}\text { Internationalisation: Europe (Western Europe in particular the Netherlands and the UK); } \\
\text { Outside Europe (Japan, USA, Russia, Middle East, China). }\end{array}$ & Turnover \\
\hline B2 & Product innovation, process innovation and management innovation & Internationalisation \\
\hline NT: 2, IT: 3 & $\begin{array}{l}\text { Internationalisation: Europe (all the countries); Outside Europe (in particular India and South } \\
\text { Korea) }\end{array}$ & Innovation \\
\hline B3 & Process innovation (to increase efficiency and reduce costs) & Resilience \\
\hline NT: 3 , IT: 3 & $\begin{array}{l}\text { Internationalisation: Europe (Germany, Eastern Europe); Outside Europe (North America, } \\
\text { Western Africa, Middle East, Japan, USA). }\end{array}$ & Strategic assets \\
\hline B4 & Product innovation, process innovation and management innovation & Keep the production \\
\hline NT: 2 , IT: 2 & Internationalisation: Europe (France, Germany, UK); Outside Europe (Egypt, Iran, Israel). & $\begin{array}{l}\text { in Italy } \\
\text { Innovation } \\
\text { Internationalisation }\end{array}$ \\
\hline B5 & Management innovation & Consolidation \\
\hline NT: 1, IT: 2 & Internationalisation: Europe (Spain and other countries with logistic benefits) & $\begin{array}{l}\text { Collaboration with } \\
\text { competitors } \\
\text { Internationalisation }\end{array}$ \\
\hline $\mathrm{C} 1$ & Product innovation, process innovation and management innovation & Turnover \\
\hline NT: 2, IT: 3 & Internationalisation: Europe (Spain, France, Germany); Outside Europe (North Africa). & Internationalisation \\
\hline $\mathrm{C} 2$ & Process innovation and management innovation & Consolidation \\
\hline NT: 2, IT: 3 & $\begin{array}{l}\text { Internationalisation: Europe (Spain); Outside Europe (Latin America, Arab countries and } \\
\text { Northern Africa) }\end{array}$ & Internationalisation \\
\hline $\begin{array}{l}\text { C3 } \\
\text { NT: } 3\end{array}$ & Process innovation and management innovation & $\begin{array}{l}\text { New points of sales in } \\
\text { Italy }\end{array}$ \\
\hline $\mathrm{C} 4$ & Process innovation and management innovation & Internationalisation \\
\hline NT: 2, IT: 3 & $\begin{array}{l}\text { Internationalisation: Europe (Spain, Germany, France, Portugal, Poland, Macedonia); Outside } \\
\text { Europe (Russia, Northern Africa and South Africa, Latin America, USA) }\end{array}$ & \\
\hline $\mathrm{C} 5$ & Product innovation, process innovation and management innovation & Turnover \\
\hline IT: 2 & Internationalisation: Europe (almost all countries); Outside Europe (Asia) & Innovation \\
\hline
\end{tabular}

*NT=National turnover: $1=$ decrease; $2=$ steady; $3=$ increase.

**IT=International turnover: $1=$ decrease; $2=$ steady; $3=$ increase.

These two typologies present a remarkable difference if we compare current and future goals. While both innovation-based growth and internationalisation-based growth have equal importance amongst the current goals, internationalisation-based growth assumes a greater importance in relation to the future goals. Also noteworthy is the importance given to 'firm survival' (equal to innovation-based growth), to firm economic performance and to the Italian business context. A more exhaustive mapping of the growth goals of family businesses is depicted in Table 7, in which the goals of future growth are presented according to the priority given by the interviewees when considering the future strategic development of the company. 
From the data analysis emerged that innovation and internationalisation are perceived as very important goals for the growth of the businesses and that they were both pursued by many types of firms (the only exceptions are A3 and C3). In particular, all the firms have implemented organisational innovation; only two do not mention the processes of innovation and 9 have innovated their products. In the past, 13 firms have focused their efforts on internationalisation. In the majority of the case studies (A2, A4, B1, B2, B4, C2, C4, C5) the international sales volume accounts for more than $60 \%$ of national sales and in 5 case studies (A4, B1, B2, B4, C5) it exceeds $90 \%$. All the companies have adopted internationalisation strategies targeting the European market and others, with one exception. For B5 the choice of countries followed an assessment related to logistic costs linked to the characteristics of the product so that the sales mainly targeted the European market, in particular Spain and other countries that possessed advantages from the logistic point of view. In all the case studies, there has been an international focus by following a very similar rationale. The firms indeed started to target markets which were geographically and culturally proximate, then those that were gradually more distant. For example, C2 (whose international revenues represent $80 \%$ of total sales), targeted Europe first, then Latin America and only later the Arab countries and North Africa. In two cases, however, the situation was exactly the opposite. B1, whose international revenues account for $90 \%$ of the total sales, made its first entry in foreign markets by targeting Japan and the United States, then Western Europe and later more distant countries such as Russia, Middle East and China. A similar pattern can be detected in relation to B3 which targeted North America first, then Europe and later the more distant markets of West Africa, Middle East and Japan. Only for two firms was there a strong interest in the context of Italian business (for both past and future growth goals). The interviewee from B4 says explicitly that he would maintain the production in Italy, even though the industry trend is for implanting offshoring, focusing on internationalisation and innovation. This is also explained in the report of Unioncamere (2014, p. 4) whereby "firms that do not consider moving their production abroad to take full advantage of lower labour costs thank to their attachment and responsibility toward their employees and their local community." For example, for C3 the main current and future goals are to remain in Italy with the ultimate aim of further increasing its affiliate network (already 55 retail stores under its own brand). Among the goals of future growth we still find innovation and internationalisation, but a different priority has been given by each interviewee. Internationalisation is in 11 case studies (A1, A2, A4, A5, B1, B2, B4, B5, C1, C2, C3) a goal to strive for in the future while for 6 cases (A1, A2, $\mathrm{A} 5, \mathrm{~B} 1, \mathrm{~B} 2, \mathrm{C} 4)$ it is an absolute priority. Those who stated that internationalisation is their priority for future growth have already adopted some internationalisation strategy in the past and have also focused on innovation. The same applies to innovation. For example, A3 has always focused only on innovation and it will continue to do so in the future. Innovation, however, is mentioned in 4 case studies and in only three of these (A2, B2, B4) has been coupled with internationalisation. Only for A3 is innovation a more important priority than internationalisation due to high logistics costs for the purchase of materials that would reduce its profit margins. In relation to the economic goals related to the business (NFC-EC), it was noted that in only 5 case studies (A4, A5, B1, C1, C5) are growth targets supported by the explicit objective of sales volume and in only 3 case studies (A4, $\mathrm{C} 1, \mathrm{C} 5$ ) does it represent the higher priority. Considering, then, the goals related to the family, the findings suggest that none of the interviewees is planning to reduce the involvement of the family in the ownership, in the executive board and in the top management; nor did they mention the idea of opening the company to external members. Therefore, we can consider these economic objectives as distinctive of family firms. At the same time, non-economic goals linked to the family are never explicitly mentioned amongst the future goals by the interviewees. This evidence contradicts the most recent literature about the relevance that family members give to non-economic goals adoption (among others, see for example Chua et al. 2015). Furthermore, amongst the non-economic future goals we find 'consolidation of the position reached', which occurs in 4 case studies (A2, A4, B5, C2). 'Gradual growth' could be a further emerging feature that distinguishes the future growth path of family businesses. The findings are further supported by some evidence found in the latest report of Unioncamere (2014, p. 4), "family businesses tend to have broader goals rather than merely maximising profit in the short-term". The importance attributed to non-economic goals in the vision of the future growth path, however, is limited only to those outside the family sphere. Such importance, however, appears to be meaningful only with reference to family involvement in the ownership, the executive board and top management; there is no reference in any case studies to the family wealth.

\section{Conclusions, Limitations and Directions for Future Research}

The contribution of the study is threefold. First, it provides a comprehensive review of the main family business goal setting models in order to identify the relevant categories used to classify the goals. In particular, the study responded to the need outlined by Chrisman et al (2012) by complementing the taxonomy proposed by Kotlar and De Massis (2013).

Second, differently from extant research the study outlines the pivotal importance of innovation and 
internationalization as strategic goals for the family firms' growth. For instance, from the data analysis emerged that innovation and internationalisation are perceived as very important goals for the growth of the businesses and that they were both pursued by many types of firms. In particular, all the firms have implemented organisational innovation.

Thirdly, by relying on a narrative approach, two other specific contributions are made. The study provides a finer-grained understanding of how internationalization and innovation are conceived with respect to traditional characteristics of the family firms. Specifically, from the findings it emerges that internationalization is the most important strategic goal for family firms' future growth. However, its adoption tends to be a gradual process due both to the limited resources that traditionally characterize family firms and to the family business's prudential approach that is aimed at preserving the family's wealth. The other specific contribution relates to the need to distinguish between current and future goals. In particular, our work shows that studying the processes in a family firm using a narrative approach can be very productive. Many entrepreneurial dynamics are performed in language-use, especially those relating practices such as organizing, launching, setting the future goals, and so on. As underlined by Dawson and Hjorth (2011, p. 9): "A narrative approach can help address family business phenomena in a way that goes beyond calculation and strategic decision making, by encompassing the lively, moving, creative, and dramatic characteristics of family relationships". Thus, a narrative approach can offer new ways of studying family business and investigating new problems such as those regarding the way entrepreneurs adopt economic and non-economic goals which are strong predictors of positive firm behaviour and performance.

From the analysis of the narrative materials some interesting aspects tend to emerge. First of all the interviewees never mentioned the role that family-centred non-economic goals plays in the future performance of the family firms: 'family values', 'resilience' and the 'strategic guidance of the family' have been listed amongst the current goals but they do not appear amongst the future goals. Secondly, from the data emerged that innovation and internationalisation are, in the vision of the family members, two key-growth drivers. Therefore, this study proposes to integrate the taxonomy of Kotlar and De Massis (2013) introducing, with reference to the NFC-E, two subcategories of firm growth goals. These are namely the innovation-based growth and the internationalisation-based growth. Even if the internationalisation is a very important goal for the future growth of the family business, the data analysis reveals that its adoption is still gradual due to the limited resources that traditionally characterise family firms and to the family business's prudential approach that is aimed at preserving the family's wealth (although this wealth was not specifically mentioned by the interviewees).

This work is only a first attempt to conduct an in-depth investigation about the importance of economic and non-economic family goals and how family firms perceive their future growth trajectories. As such the research has a large number of limitations. Nevertheless, this study could foster the basis for further research. A particularly interesting area that deserves further attention is to determine the validity of the results by also performing some statistical tests on a larger sample of family businesses and by considering the influence of the industry on the determination of the growth goals. Another interesting area of research regards the applications of a cross cultural perspective in order to detect family business goals according to the different cultural contexts.

\section{References}

Abell, P. (1987). The syntax of social life: The theory and method of comparative narratives. Oxford: Oxford University Press.

Abell, P. (2004). Narrative explanation: An alternative to variable-centered explanation? Annual Review of Sociology, 30, 287-310. https://doi.org/10.1146/annurev.soc.29.010202.100113

Amabile, T. M., Patterson, C., Mueller, J., Wojcik, T., Odomirok, P. W., Marsh, M., et al. (2001). Academic-practioners collaboration in management research: A case of cross-profession collaboration. Academy of Management Journal, 44(2), 418-431. https://doi.org/10.5465/3069464

Argote, L., \& Greve, H. R. (2007). A behavioral theory of the firm-40 years and counting: Introduction and impact. Organization Science, 18(3), 337-349. https://doi.org/10.1287/orsc.1070.0280

Arregle, J. L., Hitt, M. A., Sirmon, D. G., \& Very, P. (2007). The Development of Organizational Social Capital: Attributes of Family Firms. Journal of Management Studies, 44(1), 73-95. https://doi.org/10.1111/j.1467-6486.2007.00665.x

Astrachan, J. H., \& Jaskiewicz, P. (2008). Emotional returns and emotional costs in privately held family businesses: Advancing traditional business valuation. Family Business Review, 21(2), 139-149. https://doi.org/10.1111/j.1741-6248.2008.00115.x

Basco, R. (2017). Where do you want to take your family firm? A theoretical and empirical exploratory study of 
family business goals. BRQ Business Research Quarterly, 20, 28-44. https://doi.org/10.1016/j.brq.2016.07.001

Boje, D. M. (1991). The storytelling organization: A study of story performance in an office-supply firm. Administrative Science Quarterly, 36(1), 106-126.

Berrone, P., Cruz, C., Gómez-Mejia, L. R., \& Larraza, M. (2010). Socioemotional wealth and organizational response to institutional pressures: do family controlled firms pollute less? Administrative Science Quarterly, 55, 82-113. https://doi.org/10.2189/asqu.2010.55.1.82

Berrone, P., Cruz, C., \& Gomez-Mejia, L. R. (2012). Socioemotional wealth in family firms theoretical dimensions, assessment approaches, and agenda for future research. Family Business Review, 25(3), 258-279. https://doi.org/10.1177/0894486511435355

Boyce, M. E. (1996). Organizational story and storytelling: a critical review. Journal of Organizational Change Management, 9(5), 5-26. https://doi.org/10.1108/09534819610128760

Brown, A. D. (2006). A narrative approach to collective identities. Journal of Management Studies, 43, 731-753. https://doi.org/10.1111/j.1467-6486.2006.00609.x

Bruner, J. (1986). Actual minds, possible worlds. Cambridge, MA: Harvard University Press.

Bruner, J. (1990). Acts of meaning. Cambridge. MA: Harvard University Press.

Chrisman, J. J., Chua, J. H., \& Litz, R. A. (2004). Comparing the agency costs of family and non-family firms: conceptual issues and exploratory evidence. Entrepreneurship Theory \&Practice, 28(4), 335-354. https://doi.org/10.1111/j.1540-6520.2004.00049.x

Chrisman, J. J., Chua, J. H., \& Sharma, P. (2005). Trends and directions in the development of a strategic management theory of the family firm. Entrepreneurship Theory and Practice, 29(5), 555-576. https://doi.org/10.1111/j.1540-6520.2005.00098.x

Chrisman, J. J., Chua, J. H., Pearson, A. W., \& Barnett, T. (2012). Family involvement, family influence, and family-centered non-economic goals in small firms. Entrepreneurship Theory and Practice, 36(2), 267-293. https://doi.org/10.1111/j.1540-6520.2010.00407.x

Chua, J. H., Chrisman, J. J., \& Sharma, P. (1999). Defining the Family Business by Behavior. Entrepreneurship Theory and Practice, 23(4), 19-39. https://doi.org/10.1177/104225879902300402

Chua, J. H., Chrisman, J. J., \& De Massis, A. (2015). A closer look at socioemotional wealth: its flows, stocks, and prospects for moving forward. Entrepreneurship Theory and Practice, 39(2), 173-182. https://doi.org/10.1111/etap.12155

Cyert, R. M., \& March, J. G. (1963). A behavioral theory of the firm. Englewood Cliffs, NJ: Prentice-Hall.

Cortese, C. G. (1999). L'organizzazione si racconta. Perchè occuparsi di cose che effettivamente sono tutte storie. Milano: Guerini e Associati.

Creswell, J. (2007). Qualitative inquiry \& research design: Choosing among five approaches (2nd ed.). Thousand Oaks, CA: Sage.

Czarniawska, B. (1997). Narrating the organization: Dramas of institutional identity. Chicago: University of Chicago Press.

Czarniawska, B. (1998). A narrative approach to organization studies. Thousand Oaks, CA: Sage.

Dawson, A., \& Hjorth, D. (2011). Advancing family business research through narrative analysis. Family Business Review, 25(3), 339-355. https://doi.org/10.1177/0894486511421487

Della, P. B., \& Vecchi, A. (2017). The Internationalization of a Family Business Group: The Ownership, the Leadership and the importance of the Socio-Emotional Wealth. Management Research: Journal of the Iberoamerican Academy of Management, 15(4), 380-404. https://doi.org/10.1108/MRJIAM-02-2016-0642

Della, P. B., Vecchi, A., \& Jimenez, A. (2018). Embracing a new perspective on the governance of Family Business Groups: a cross-cultural perspective. European Journal of International Management, 12(3), 223-254. https://doi.org/10.1504/EJIM.2018.091368

De Massis, A., \& Kotlar, J. (2014). The case study method in family business research: Guidelines for qualitative scholarship. Journal of Family Business Strategy, 5, 15-29. https://doi.org/10.1016/j.jfbs.2014.01.007

De Massis, A., Kotlar, J., Campopiano, G., \& Cassia, L. (2013). Dispersion of family ownership and the 
performance of small-to-medium size private family firms. Journal of Family Business Strategy, 4(3), 166-175. https://doi.org/10.1016/j.jfbs.2013.05.001

Denning, S. (2004). Telling tales. Harvard Business Review, 82(5), 122-129.

Denzin, N. K. (1994). Introduction: Entering the field of qualitative research. In N.K. Denzin and Y.S. Lincoln (Eds.), Handbook of qualitative research (pp. 1-17). London: Sage Publishing.

Dyer, W. G., \& Whetten, D. A. (2006). Family firms and social responsibility: Preliminary evidence from the S\&P 500. Entrepreneurship Theory and Practice, 30(6), 785-802. https://doi.org/10.1111/j.1540-6520.2006.00151.x

Eisenhardt, K. M., \& Graebner, M. E. (2007). Theory building from cases: opportunities and challenges. Academy of Management Journal, 50(1), 25-32.

Freeman, R. E. (2010). Strategic management: A stakeholder approach. Cambridge: University Press.

Fisher, W. R. (1987). Human communication as narration: towards a philosophy of reason, value, and action. Columbia: University of South Carolina Press.

Fisher, W. R. (1984). Narration as a human communication paradigm: The case of public moral argument. Communication Monographs, 51, 1-22. https://doi.org/10.1080/03637758409390180

Franzosi, R. (1998). Narrative analysis, or why (and how) sociologists should be interested in narrative. Annual Review of Sociology, 24, 517-54. https://doi.org/10.1146/annurev.soc.24.1.517

Geertz, C. (1993). The interpretation of cultures. London: Fontana Press.

Geertz, C. (1988). Works and lives. Stanford, CA: Stanford University Press.

Gómez-Mejía, L. R., Haynes, K. T., Núñez-Nickel, M., Jacobson, K. J., \& Moyano-Fuentes, J. (2007). Socioemotional wealth and business risks in family-controlled firms: Evidence from Spanish olive oil mills. Administrative Science Quarterly, 52(1), 106-137. https://doi.org/10.2189/asqu.52.1.106

Habbershon, T., \& Pistrui, J. (2002). Enterprising families domain: family-influenced ownership groups in pursuit of transgenerational wealth. Family Business Review, 15(3), 223-237. https://doi.org/10.1111/j.1741-6248.2002.00223.x

Hamilton, E., Crus, A. D., \& Jack, S. (2917). Re-framing the status of narrative in family business research: Towards an understanding of families in business. Journal of Family Business Strategy, 8, 3-12. https://doi.org/10.1016/j.jfbs.2016.11.001

Izzo F. (2018). Il mestiere di crescere: strategie e performance delle medie imprese industriali del Mezzogiorno, ES Editoriale Scientifica.

Jick, T. D. (1979). Mixing qualitative and quantitative methods: Triangulation in action. Administrative Science Quarterly, 24(4), 602-611.

Kallmuenzer, A., \& Peters, M. (2017). Exploring entrepreneurial orientation in family firms: the relevance of social embeddedness in competition. Int. J. Entrepreneurship and Small Business, 30(2), 191-213.

Kotlar, J., \& De Massis, A. (2013). Goal setting in family firms: Goal diversity, social interactions, and collective commitment to family-centered goals. Entrepreneurship Theory and Practice, 37(6),1263-1288. https://doi.org/10.1111/etap.12065

Leonard-Barton, D. (1990). A dual methodology for case studies: Synergistic use of a longitudinal single site with replicated multiple sites. Organization Science, 1(3), 248-266.

Marsiglio, W., \& Cohan, M. (2000). Contextualizing father involvement and paternal influence. Marriage \& Family Review, 29(2/3): 75-95. https://doi.org/10.1287/orsc.1.3.248

McCloskey, D. N. (1985). The rhetorics of economics. Madison: University of Wisconsin Press.

Merriam, S. (2009). Qualitative research: A guide to design and implementation. San Francisco, CA: Jossey-Bass.

Milton, L. P. (2008). Unleashing the relationship power of family firms: Identity confirmation as a catalyst for performance. Entrepreneurship Theory and Practice, 32(6), 1063-1081. https://doi.org/10.1111/j.1540-6520.2008.00273.x

Mitchell, R. K., Agle, B. R., \& Wood, D. J. (1997). Toward a theory of stakeholder identification and salience: Defining the principle of who and what really counts. Academy of Management Review, 22(4), 853-886. https://doi.org/10.5465/amr.1997.9711022105 
Mitroff, I. I., Kilmann, R. H. (1975). Stories managers tell: A new tool for organizational problem solving. Management Review, 64(7), 18-28.

Nordquist, M., \& Melin, L. (2010). Entrepreneurial families and family firms. Entrepreneurship \& Regional Development, 22(3), 211-239. https://doi.org/10.1080/08985621003726119

O’Connor, E. S. (1995). Paradoxes of participation: Textual analysis and organization change. Organization Studies, 16(5), 769-803. https://doi.org/10.1177/017084069501600502

Oliver, D., \& Roos, J. (2005). Decision-making in high-velocity environments: The importance of guiding principles. Human Relations, 26, 889-913. https://doi.org/10.1177/0170840605054609

Parada, M. J, \& Viladás, H. (2010). Narratives: a powerful device for values transmission in family business. Journal of Organizational Change Management, 23(2), $166-172$. https://doi.org/10.1108/09534811011031346

Pearson, A. W., Carr, J. C., \& Shaw, J. C. (2008). Toward a theory of familiness: A social capital perspective. Entrepreneurship Theory and Practice 32(6), 949-969. https://doi.org/10.1111/j.1540-6520.2008.00265.x

Pettigrew, A. M. (1990). Longitudinal field research on change: Theory and practice. Organization Science, 1(3), 267-292. https://doi.org/10.1287/orsc.1.3.267

Polkinghorne, D. (1988). Narrative knowing and the human sciences. Albany: State University of New York Press.

Rappaport, J. (1993). Narrative studies, personal stories, and identity transformation in the mutual help context. Journal of Applied Behavioral Science, 29, 239-256. https://doi.org/10.1177/0021886393292007

Rosenthal, G., \& Fischer-Rosenthal, W. (2004). The analysis of narrative-biographical interviews. In Flick, Uwe, von Kardorff, Ernst, Steinke, Ines, A companion to qualitative research, London Sage, 259-265 (in German 2000).

Sharma, P. (2004). An overview of the field of family business studies: Current status and directions for the future. Family Business Review, 170, 1-36. https://doi.org/10.1111/j.1741-6248.2004.00001.x

Sharma, P., Chrisman, J. J., Pablo, A. L., \& Chua, J. H. (2001). Determinants of initial satisfaction with the succession process in family firms: A conceptual model. Entrepreneurship Theory and Practice, 25(3), 17-36. https://doi.org/10.1177/104225870102500302

Singh, R., \& Kota, H. B. (2017). A resource dependency framework for innovation and internationalization of family businesses: Evidence from India. Journal of Entrepreneurship in Emerging Economies, 9(2). 207-231. https://doi.org/10.1108/JEEE-04-2016-0013

Sonfield, M. C., \& Lussie, R. N. (2004). First-, second-, and third-generation family firms: A comparison. Family Business Review, 17, 189-202. https://doi.org/10.1111/j.1741-6248.2004.00013.x

Stake, R.E. (2013). Multiple case study analysis. New York: Guilford Press.

Starkey, K., \& Crane, A. (2003). Toward green narrative: Management and the evolutionary epic. Academy of Management Review, 28, 220-237. https://doi.org/10.5465/amr.2003.9416086

Thomas, S. (2012). Narrative inquiry: Embracing the possibilities. Qualitative Research Journal, 12(2), 206-221.https://doi.org/10.1108/14439881211248356

Thompson, C. J. (1997). Interpreting consumers: A hermeneutical framework for deriving marketing insights from the texts of consumers' consumption stories. Journal of Marketing Research, 34, 438-455.

Van Riel, C. B. M. (2000). Corporate communication orchestrated by sustainable corporate story. In The Expressive Organization: Linking Identity, Reputation, and the Corporate Brand: Linking Identity, Reputation, and the Corporate Brand. Ed. Shultz, M., Hatch, M.J. \& Larsen, H. Oxford: Oxford University Press.

Westhead, P., \& Howorth, C. (2006). Ownership and management issues associated with family firm performance and company objectives. Family Business Review, 19, 301-316. https://doi.org/10.1111/j.1741-6248.2006.00077.x

Westhead, P., \& Cowling, M. (1998). Family firm research: The need for a methodological rethink. Entrepreneurship Theory and Practice, 23, 31-56. https://doi.org/10.1177/104225879802300102

Williams Jr, R. I., Pieper, T. M., Kellermanns, W. F., \& Atrachan, J. H. (2018). Family firm goals and their effects on strategy, family and organization behavior: a review and research agenda. International Journal of Management Reviews, 20, S68-S82. https://doi.org/10.1111/ijmr.12167 
Yin, R. K. (1994). Case study research: design and methods. Thousand Oaks, CA: Sage.

Yin, R. K. (2011). Applications of case study research. Thousand Oaks, CA: Sage.

Zellweger, T. M., \& Astrachan, J. H. (2008). On the emotional value of owning a firm. Family Business Review, 21(4), 347-363. https://doi.org/10.1177/08944865080210040106

Zellweger, T. M., Kellermanns, F. W., Chrisman, J. J., \& Chua, J. H. (2012). Family control and family firm valuation by family CEOs: The importance of intentions for transgenerational control. Organization Science, 23(3), 851-868. https://doi.org/10.1287/orsc.1110.0665

Zellweger, T., \& Sieger, P. (2012). Entrepreneurial orientation in long-lived family firms. Small Business Economics, 38(1), 67-84. https://doi.org/10.1007/s11187-010-9267-6

Zellweger, T. M., Nason, R. S., Nordqvist, M., \& Brush, C. G. (2012). Why do family firms strive for nonfinancial goals? An organizational identity perspective. Entrepreneurship Theory \& Practice, 37(2), 229-248. https://doi.org/10.1111/j.1540-6520.2011.00466.x

\section{Copyrights}

Copyright for this article is retained by the author(s), with first publication rights granted to the journal.

This is an open-access article distributed under the terms and conditions of the Creative Commons Attribution license (http://creativecommons.org/licenses/by/4.0/). 